\title{
Studi Fenomenologi Tentang Keseimbangan Kehidupan dan Pekerjaan Karyawan Sektor Perbankan di Kota Semarang
}

\author{
Mochammad Eric Suryakencana Wibowo \\ Universitas Diponegoro \\ Evanea S. Hartono \\ Universitas Diponegoro \\ ericsuryaa@gmail.com
}

\begin{abstract}
Abstrak
Tujuan dari penelitian ini adalah untuk menganalisis seperti apa keseimbangan antara kehidupan pribadi dan urusan pekerjaan dari para karyawan sektor perbankan. Apakah para karyawan sektor perbankan mampu mengatur dan membagi tanggung jawabnya atau justru sebaliknya, dimana kedua hal tersebut diketahui seringkali menimbulkan masalah, terutama bagi mereka-mereka yang bekerja dan telah berkeluarga. Penelitian ini melibatkan sebanyak 7 partisipan yang berprofesi sebagai karyawan bank swasta di Kota Semarang. Metode kualitatif dengan pendekatan fenomenologi digunakan pada penelitian ini. Pengambilan data dilakukan secara langsung kepada para partisipan dengan menggunakan wawancara mendalam guna memperoleh data primer penelitian yang kemudian data tersebut diolah dengan menggunakan Interpretative Phenomenological Analysis (IPA). Hasil penelitian menunjukkan bahwa antara kehidupan pribadi dan urusan pekerjaan adalah dua hal yang berbeda. Keduanya tidak dapat dicampuradukkan, namun keduanya berada pada skala prioritas utama yang harus dilakukan. Partisipan merasa harus bertanggung jawab dalam mengurus berbagai hal dalam kehidupan pribadinya dan menyelesaikan urusan pekerjaannya. Masing-masing kehidupan tidak serta merta dapat mengisi kekurangan satu sama lain, karena keduanya telah memiliki porsi yang sama dan menempati skala prioritas utama untuk dijalankan.
\end{abstract}

Kata Kunci: Karyawan perbankan, kehidupan pribadi, urusan pekerjaan, kualitatif, fenomenologi, IPA, skala prioritas utama, kehidupan berbeda.

\section{Pendahuluan}

Konsep tentang keseimbangan kehidupan dan pekerjaan menjadi menarik untuk diteliti. Keseimbangan merupakan topik pembicaraan yang sering kita dengar. Keseimbangan berarti tidak berat pada satu sisi dan juga tidak ringan pada sisi lainnya. Namun faktanya, keseimbangan dapat menjadi masalah ketika bobot atau porsinya tidak sama dan tidak sepadan. Hal-hal paling dominan yang sering ditemui oleh seseorang terkait ketidakseimbangan dalam dunia kerja adalah ia tidak memiliki cukup waktu, tidak memiliki dukungan penuh untuk melakukan sesuatu, tidak cakap untuk menanganinya, tidak cermat untuk mengelola, dan merasa terhimpit oleh komitmen kerja dan tanggung jawab pribadi (Lockwood, 2003). Ditengah derasnya arus globalisasi dan kemajuan teknologi, yang paling merasakan dampak dari ketidakseimbangan antara kehidupan dan pekerjaan adalah karyawan korporasi. Para karyawan ini dituntut agar mampu bertanggung jawab dalam membagi waktu 


\section{Mochammad Eric Suryakencana Wibowo, Evanea S. Hartono}

ditengah-tengah kesibukannya. Namun, seringkali mereka tidak dapat melakukan apa yang menjadi tanggung jawabnya secara baik dan maksimal. Terlebih bagi mereka-mereka yang bekerja di sektor perbankan, hal ini tentunya menjadi problematika tersendiri. Seperti kita ketahui, sektor perbankan memainkan peran yang sangat penting dalam sebuah perekonomian nasional. Banyak orang di Indonesia membangun karirnya di bidang perbankan. Mereka menyebut bahwa stabilitas pekerjaan, ruang lingkup untuk orang-orang dari disiplin ilmu yang beragam dapat diterima bekerja pada sektor ini. Faktor lainnya, seperti pendapatan yang baik dan tunjangan tambahan yang menarik semakin menjadikan orangorang banyak mengejar lapangan pekerjaan ini (Rahman, 2019).

Namun di sisi lain, para karyawan yang bekerja di sektor perbankan seringkali dituntut untuk dapat bersikap profesional dalam menyelesaikan urusan pekerjaannya. Padahal, mereka juga memiliki kehidupan pribadi yang juga harus mereka urus. Sektor perbankan saat ini bergerak ke arah yang lebih kompetitif di mana bank-bank menawarkan lebih banyak variasi produk keuangan dan pemutakhiran layanan. Namun di balik semua itu, para karyawan bank tidak dapat menikmati fleksibilitas dari apa yang mereka lakukan secara penuh, dan hal ini merupakan salah satu faktor resiko dari profesi yang mereka jalani (Hossain et al., 2018). Karyawan di bank berusaha keras untuk melayani berbagai kebutuhan nasabahnya. Tenggat waktu kerja yang semakin padat dan target pekerjaan yang berat, tentunya memunculkan perasaan bekerja dalam tekanan, namun tetap sulit menyeimbangkan antara profesionalitas kerja dan melayani keluarga. Jika hal demikian yang terjadi, maka semua bergantung pada kualitas sumber daya manusia masing-masing (Rajendran \& Geetha, 2017).

Hal lain yang disoroti dari profesi karyawan bank adalah ketidakmampuan dalam menyeimbangkan kehidupan. Akibatnya mereka merasakan depresi, gangguan mental, perasaan tidak ingin masuk kerja, sampai dengan keputusan untuk berhenti kerja (Franche et al., 2006). Tekanan kerja menimbulkan pergolakan dan menuntut seseorang untuk memiliki waktu lebih dan mendorong kemampuan diri secara maksimal. Tentu ini menjadi sumber tekanan bagi karyawan (Guest, 2002). Masalah lain yang terjadi pada sektor perbankan adalah durasi jam kerja yang tinggi. Telah banyak kasus terjadi bahwa karyawan masih harus menerima email atau pesan yang terkait dengan urusan pekerjaan di luar jam kantor atau ketika mereka telah berada di rumah. Seharusnya perusahaan wajib memberikan fleksibilitas kepada karyawannya agar dapat mengatur aktivitas dan membagi waktu luang, sehingga karyawan bisa berkomitmen kepada diri sendiri, memiliki opsi untuk bekerja dari rumah, dan mengambil waktu rehat atau cuti guna membantu mereka dalam menjaga keseimbangan kehidupan dan pekerjaan secara tepat (Rajendran \& Geetha, 2017).

Fenomena menyangkut ketidakseimbangan kehidupan dan pekerjaan bukan hanya menjadi masalah global, akan tetapi juga terjadi di Indonesia. Karyawan menginginkan fleksibilitas dan kendali atas pekerjaan, termasuk kinerja mereka. Penelitian sebelumnya mengungkapkan efek pemberian gaji dan kompensasi dapat membentuk dua istilah yang dapat menimbulkan gangguan psikologis, yakni work-to-family dan family-to-work. Secara khusus, efek dari dua domain tersebut memiliki dampak penting satu sama lain (Lockwood, 2003). Masalah-masalah menyangkut ketidakseimbangan antara kehidupan dan pekerjaan, khususnya yang berhubungan dengan hal-hal eksternal di luar pekerjaan, selalu dipandang sebagai konsekuensi dari pekerjaan itu sendiri. Kehidupan pribadi dari seorang individu dan segala aktivitasnya di luar urusan pekerjaan, justru seringkali dipandang sebagai awal mula masalah yang mengakibatkan ketidakseimbangan antara kehidupan dan pekerjaan (Guest, 2002). Fenomena tersebut semakin diperkuat oleh hasil dari kegiatan pra survei yang dilakukan sebelum peneliti mengambil data primer di lokasi obyek penelitian. 
Pada kegiatan pra survei tersebut, peneliti telah menyiapkan pertanyaan-pertanyaan secara umum tentang keseimbangan kehidupan dan pekerjaan kepada 5 orang partisipan awal yang dipilih secara acak di sebuah bank swasta di Kota Semarang. Hasilnya, secara garis besar diketahui bahwa seluruh partisipan merasa bahwa bekerja di sektor perbankan begitu melelahkan. Banyak waktu yang tersita dan mereka masih harus meluangkan waktu ekstra di luar jam bekerja guna menyelesaikan urusan pekerjaan. Mengingat pekerjaan di bank begitu menguras tenaga, pikiran, dan waktu, mereka menjadi merasa kehilangan fokus dan tidak menemukan kesenangan dalam menjalankan keseharian maupun melakukan berbagai aktivitas pada kehidupan pribadi. Berbekal temuan awal ini, peneliti semakin yakin bahwa penelitian ini harus dilanjutkan dengan pengambilan data primer. Temuan ini menjadi indikasi awal bahwa terdapat masalah-masalah seputar keseimbangan kehidupan dan pekerjaan dari para karyawan di sektor perbankan.

Tabel 1.

Hasil Pra Survei Karyawan Bank di Kota Semarang

\begin{tabular}{|c|c|c|}
\hline \multicolumn{3}{|c|}{$\begin{array}{l}\text { Kehidupan Pribadi Mengganggu Pekerjaan } \\
\text { (Personal Life Interference with Work (PLIW)) }\end{array}$} \\
\hline No. & Pertanyaan & Hasil Pra Survei \\
\hline 1. & $\begin{array}{l}\text { Apakah Anda masih } \\
\text { bersemangat melakukan } \\
\text { berbagai aktivitas setelah } \\
\text { sepulang bekerja? }\end{array}$ & $\begin{array}{l}\text { Terdapat } 2 \text { orang menjawab masih sanggup melakukan } \\
\text { kegiatan sesampainya di rumah, seperti memasak, } \\
\text { memandikan anak, menyiapkan pakaian untuk esok hari, } \\
\text { dan menonton televisi. Sementara, } 3 \text { orang lainnya } \\
\text { menjawab bahwa mereka tidak sanggup melakukan } \\
\text { aktivitas apapun karena kelelahan. Mereka biasanya } \\
\text { akan langsung mandi dan beristirahat. }\end{array}$ \\
\hline 2. & $\begin{array}{l}\text { Apakah Anda tetap tidak } \\
\text { ingin mengabaikan } \\
\text { kebutuhan pribadi } \\
\text { meskipun terdapat } \\
\text { tuntutan pekerjaan yang } \\
\text { terus membayangi ketika } \\
\text { Anda telah berada di } \\
\text { rumah? }\end{array}$ & $\begin{array}{l}\text { Sebanyak } 5 \text { orang partisipan atau seluruhnya menjawab } \\
\text { bahwa kebutuhan pribadi tetap harus diutamakan. } \\
\text { Urusan pekerjaan dapat dilanjutkan dan diselesaikan } \\
\text { setelah segala keperluan sehari-hari dan kebutuhan } \\
\text { pribadi terpenuhi. }\end{array}$ \\
\hline 3. & $\begin{array}{l}\text { Apakah Anda pernah } \\
\text { merasa bahwa berbagai } \\
\text { aktivitas pribadi Anda } \\
\text { justru lebih } \\
\text { menyenangkan untuk } \\
\text { dilakukan, bahkan sampai } \\
\text { harus mengorbankan } \\
\text { waktu untuk } \\
\text { menyelesaikan pekerjaan? }\end{array}$ & $\begin{array}{l}\text { Sebanyak } 5 \text { orang partisipan atau seluruhnya menjawab } \\
\text { bahwa mereka sering menghabiskan waktu untuk } \\
\text { melakukan aktivitas pribadi, meskipun hal tersebut } \\
\text { mengorbankan waktu bekerja. Berbagai aktivitas pribadi } \\
\text { tersebut biasanya lebih banyak dilakukan pada waktu } \\
\text { akhir pekan. Dan bagi kelimanya, waktu akhir pekan } \\
\text { bukanlah saat yang tepat untuk memikirkan urusan } \\
\text { pekerjaan. }\end{array}$ \\
\hline \multicolumn{3}{|c|}{$\begin{array}{l}\text { Pekerjaan Mengganggu Kehidupan Pribadi } \\
\text { (Work Interference with Personal Life (WIPL)) }\end{array}$} \\
\hline No. & Pertanyaan & Hasil Pra Survei \\
\hline 4. & Apakah pekerjaan Anda & Sebanyak 5 orang partisipan atau seluruhnya \\
\hline
\end{tabular}




\section{Mochammad Eric Suryakencana Wibowo, Evanea S. Hartono}

\begin{tabular}{|c|c|c|}
\hline & $\begin{array}{l}\text { sangat menguras banyak } \\
\text { tenaga sehingga } \\
\text { menjadikan Anda tidak } \\
\text { memiliki sisa tenaga lagi } \\
\text { untuk melakukan kegiatan } \\
\text { di luar kantor? }\end{array}$ & $\begin{array}{l}\text { membenarkan bahwa pekerjaan mereka sebagai seorang } \\
\text { karyawan bank sangat menguras tenaga. Bahkan bukan } \\
\text { hanya tenaga, akan tetapi juga pikiran dan waktu. } \\
\text { Akibatnya, mereka tidak memiliki sisa tenaga lagi untuk } \\
\text { melakukan aktivitas berat seusai bekerja, seperti } \\
\text { berolahraga, berbelanja, hingga menemani anak-anak } \\
\text { mereka belajar dan mengerjakan tugas sekolah. }\end{array}$ \\
\hline 5. & $\begin{array}{l}\text { Apakah Anda tetap } \\
\text { bekerja secara profesional } \\
\text { dan tidak menurunkan } \\
\text { semangat sedikitpun, } \\
\text { meski Anda sedang } \\
\text { memiliki masalah atau } \\
\text { kendala yang terjadi pada } \\
\text { kehidupan pribadi Anda? } \\
\text { (Misalnya: masalah } \\
\text { keluarga, masalah } \\
\text { percintaan, masalah } \\
\text { keuangan, dll). }\end{array}$ & $\begin{array}{l}\text { Terdapat } 3 \text { orang partisipan mengaku bahwa mereka } \\
\text { tidak dapat fokus bekerja saat sedang memiliki } \\
\text { problematika dalam kehidupan pribadi mereka. Bagi } \\
\text { ketiganya, masalah yang sedang dihadapi tentu saja } \\
\text { akan terbawa sampai di kantor. Meski harus tetap } \\
\text { bersikap profesional, namun sikap, ekspresi, dan mood } \\
\text { mereka tidak dapat berbohong. Masalah yang dihadapi } \\
\text { berdampak terhadap performa dalam bekerja. } \\
\text { Sementara, } 2 \text { orang partisipan lainnya merasa bahwa } \\
\text { tetap dapat bersikap profesional dan dapat mengelola } \\
\text { pekerjaan dengan baik, sekalipun mereka sedang } \\
\text { dirundung masalah. Namun, salah seorang partisipan } \\
\text { dari keduanya menambahkan, seusai bekerja tetap saja } \\
\text { ia kembali dibayangi oleh masalah yang sedang terjadi. }\end{array}$ \\
\hline 6. & $\begin{array}{l}\text { Apakah saat bekerja, } \\
\text { Anda pernah } \\
\text { mengkhawatirkan tentang } \\
\text { berbagai hal atau aktivitas } \\
\text { yang sering dilakukan di } \\
\text { luar dari urusan } \\
\text { pekerjaan? } \\
\text { (Misalnya: melakukan } \\
\text { hobi, berorganisasi } \\
\text { masyarakat, berkumpul } \\
\text { dengan komunitas, } \\
\text { melayani orang tua dan } \\
\text { keluarga) }\end{array}$ & $\begin{array}{l}\text { Sebanyak } 5 \text { orang partisipan atau seluruhnya mengaku } \\
\text { sering mengkhawatirkan hal-hal di luar dari urusan } \\
\text { pekerjaan. Mereka khawatir akan tersitanya waktu untuk } \\
\text { berbagai kegiatan pribadi, hanya karena masih harus } \\
\text { menyelesaikan urusan pekerjaan. Tak jarang, beberapa } \\
\text { dari partisipan juga sering mengagendakan pertemuan } \\
\text { bersama teman-teman sepulang dari kantor. Ini } \\
\text { dilakukan untuk merelaksasi pikiran setelah seharian } \\
\text { penat bekerja. }\end{array}$ \\
\hline \multicolumn{3}{|c|}{$\begin{array}{l}\text { Kehidupan Pribadi Meningkatkan Kualitas Pekerjaan } \\
\text { (Personal Life Enhancement of Work (PLEW)) }\end{array}$} \\
\hline No. & Pertanyaan & Hasil Pra Surve1 \\
\hline 7. & $\begin{array}{l}\text { Apakah berbagai kegiatan } \\
\text { menyenangkan di luar } \\
\text { urusan pekerjaan yang } \\
\text { sering Anda lakukan dapat } \\
\text { mendorong diri Anda } \\
\text { untuk dapat lebih } \\
\text { produktif dan } \\
\text { meningkatkan performa } \\
\text { saat bekerja? }\end{array}$ & $\begin{array}{l}\text { Terdapat } 2 \text { orang partisipan mengatakan bahwa mereka } \\
\text { tidak terdorong oleh berbagai kegiatan menyenangkan } \\
\text { yang mereka lakukan. Hal ini terjadi karena apabila } \\
\text { mereka telah berada di kantor atau sedang menatap layar } \\
\text { laptop, mereka sama sekali tidak memikirkan berbagai } \\
\text { kegiatan dan kesenangan yang telah mereka lakukan. } \\
\text { Sementara } 2 \text { orang partisipan lainnya mengatakan } \\
\text { bahwa melakukan hal-hal menyenangkan di luar dari } \\
\text { urusan pekerjaan dapat mendorong dan memotivasi diri } \\
\text { mereka. Karena apabila bekerja dengan perasaan }\end{array}$ \\
\hline
\end{tabular}




\begin{tabular}{|c|c|c|}
\hline & & $\begin{array}{l}\text { bahagia, maka performa mereka akan meningkat dan } \\
\text { hasil yang mereka dapatkan (bonus, gaji, tunjangan) } \\
\text { akan mereka pergunakan kembali untuk melakukan } \\
\text { kesenangan dan berbagai hal yang diinginkan. } \\
\text { Sedangkan, } 1 \text { orang partisipan lainnya menjawab ragu- } \\
\text { ragu akan hal ini. Baginya, kegiatan menyenangkan } \\
\text { yang dilakukan terkadang dapat memotivasi dirinya } \\
\text { untuk dapat mencapai target pekerjaan secara maksimal, } \\
\text { akan tetapi apabila ia gagal mencapai target pekerjaan } \\
\text { tersebut maka ia akan mudah patah semangat, tidak } \\
\text { berambisi lagi untuk meraihnya, sampai dengan } \\
\text { tindakan mengabaikan target yang sebelumnya ingin ia } \\
\text { capai tersebut. Dan tentu saja, pada titik ini ia tidak } \\
\text { sekalipun terpikirkan hal-hal menyenangkan yang } \\
\text { sebelumnya ia lakukan di luar sana. }\end{array}$ \\
\hline 8 & $\begin{array}{l}\text { Apakah Anda merasa } \\
\text { kehidupan pribadi Anda } \\
\text { terbantu atau tertolong } \\
\text { oleh pekerjaan Anda saat } \\
\text { ini? }\end{array}$ & $\begin{array}{l}\text { Terdapat } 4 \text { orang partisipan menjawab secara ragu-ragu. } \\
\text { Bagi mereka, apabila mereka saat ini tidak memiliki } \\
\text { pekerjaan, maka segala kebutuhan dan keperluan hidup } \\
\text { tidak akan dapat mereka cukupi atau penuhi. Sementara } \\
\text { di sisi lain, justru pekerjaan yang telah memberikan } \\
\text { pemasukan dan pendapatan bagi mereka, sering kali } \\
\text { terasa berat dan begitu melelahkan. Mereka seperti } \\
\text { harus mengejar sesuatu yang dapat memberi mereka } \\
\text { kehidupan dan pengharapan, akan tetapi hal yang dapat } \\
\text { mendatangkan kehidupan dan pengharapan tersebut } \\
\text { justru menekan mental dan psikis mereka. Sedangkan, } 1 \\
\text { orang partisipan lainnya mengatakan dengan tegas } \\
\text { bahwa kehidupan pribadinya terpenuhi karena ia } \\
\text { bekerja. Ada kepuasan tersendiri ketika menyadari } \\
\text { bahwa dirinya dapat memberi nafkah kepada keluarga } \\
\text { dan memastikan bahwa taraf kehidupan keluarganya } \\
\text { semakin meningkat menuju ke arah sejahtera. }\end{array}$ \\
\hline \multicolumn{3}{|c|}{$\begin{array}{l}\text { Pekerjaan Meningkatkan Kualitas Kehidupan Pribadi } \\
\text { (Work Enhancement of Personal Life (WEPL)) }\end{array}$} \\
\hline No. & Pertanyaan & Hasil Pra Survei \\
\hline 9. & $\begin{array}{l}\text { Apakah aktivitas bekerja } \\
\text { di kantor dapat } \\
\text { mengalihkan pikiran Anda } \\
\text { saat Anda sedang } \\
\text { menghadapi masalah } \\
\text { pribadi? }\end{array}$ & $\begin{array}{l}\text { Terdapat } 3 \text { orang partisipan menjawab bahwa aktivitas } \\
\text { bekerja di kantor sama sekali tidak dapat mengalihkan } \\
\text { permasalahan yang sedang dialami pada kehidupan } \\
\text { pribadinya. Justru permasalahan tersebut menjadikan } \\
\text { mereka tidak fokus, menurunkan semangat dan } \\
\text { produktivitas bekerja. Kualitas bekerja justru menurun } \\
\text { dengan adanya masalah yang sedang dihadapi, begitu } \\
\text { pula kehidupan pribadi juga semakin tidak tertangani. } \\
\text { Sementara, } 2 \text { orang partisipan lainnya mengatakan } \\
\text { sanggup menjadikan aktivitas bekerja sebagai bentuk } \\
\text { "pelarian" ketika mereka sedang menghadapi suatu } \\
\text { masalah pada kehidupan pribadinya. Keduanya }\end{array}$ \\
\hline
\end{tabular}




\begin{tabular}{|c|c|c|}
\hline & & $\begin{array}{l}\text { mengaku harus bersikap profesional dengan tidak } \\
\text { mencampuradukkan masalah yang dibawa dari luar } \\
\text { kantor ke tempat mereka bekerja. }\end{array}$ \\
\hline 10. & $\begin{array}{l}\text { Apakah Anda merasa diri } \\
\text { Anda menjadi lebih baik } \\
\text { ketika sedang berada di } \\
\text { kantor dan berdampakkah } \\
\text { pada kehidupan pribadi } \\
\text { Anda? }\end{array}$ & $\begin{array}{l}\text { Terdapat } 3 \text { orang partisipan mengaku bahwa diri mereka } \\
\text { merasa lebih baik ketika berada di kantor karena } \\
\text { senioritas yang telah melekat kepada diri mereka. } \\
\text { Mereka menjadi lebih terpandang, dihormati, } \\
\text { didengarkan, diberi kesempatan untuk menyetujui suatu } \\
\text { tindakan, hingga pada kewenangan dalam pengambilan } \\
\text { keputusan. Rupanya, perasaan tersebut juga ikut terbawa } \\
\text { ketika mereka sedang berada di lingkungan sosial dan } \\
\text { organisasi kemasyarakatan. Sepenuhnya, mereka dapat } \\
\text { mengaktualisasikan diri menjadi seperti apa yang } \\
\text { mereka inginkan. Sementara, } 2 \text { orang partisipan lainnya } \\
\text { merasa biasa saja, baik itu di dalam kantor maupun di } \\
\text { luar kantor. }\end{array}$ \\
\hline 11. & $\begin{array}{l}\text { Apakah menurut Anda, } \\
\text { melalui bekerja } \\
\text { merupakan satu-satunya } \\
\text { jalan untuk menjadikan } \\
\text { kehidupan pribadi Anda } \\
\text { menjadi lebih baik dan } \\
\text { bahagia? }\end{array}$ & $\begin{array}{l}\text { Sebanyak } 5 \text { orang partisipan atau seluruhnya setuju atas } \\
\text { keterkaitan dua hal tersebut. Dengan bekerja, mereka } \\
\text { akan mendapatkan gaji dan ini otomatis akan } \\
\text { meningkatkan taraf kehidupan mereka. Disamping itu, } \\
\text { rutinitas bekerja juga telah mengenalkan mereka pada } \\
\text { dunia karir dan hubungan relasi yang luas. Manfaat lain } \\
\text { yang dirasakan oleh mereka adalah dapat melakukan } \\
\text { personal growth secara kontinyu, mampu melatih jiwa } \\
\text { kepemimpinan, mampu melakukan kegiatan } \\
\text { multitasking secara baik, mampu membahagiakan } \\
\text { keluarganya, dapat mengaktualisasikan diri seperti apa } \\
\text { yang mereka inginkan, menjadi lebih populer } \\
\text { dikalangan teman-teman, dapat menyisihkan tabungan } \\
\text { untuk beribadah, merawat orang tua, dan menghabiskan } \\
\text { waktu bersama keluarga atau pergi liburan. Namun, } \\
\text { ukuran kebahagiaan bagi kelimanya berbeda-beda. } \\
\text { Tidaklah selalu karena bekerja, maka mereka telah } \\
\text { dianggap bahagia. Jadi dalam arti, mereka sangat setuju } \\
\text { apabila melalui aktivitas bekerja, mereka akan } \\
\text { mendapatkan kehidupan yang lebih baik, namun belum } \\
\text { tentu mereka akan menemukan kebahagiaan yang } \\
\text { selama ini mereka dambakan. }\end{array}$ \\
\hline
\end{tabular}

Sumber: Hasil Wawancara Pra Survei (2020)

Maka berdasarkan fenomena-fenomena tersebut, rumusan permasalahan yang diangkat pada penelitian ini adalah tentang bagaimana karyawan sektor perbankan di Kota Semarang dapat mengatur keseimbangan kehidupan dan pekerjaannya. Oleh karena itu, tujuan dilakukannya penelitian ini adalah untuk mengidentifikasi dan menganalisis tentang bagaimana keseimbangan kehidupan dan pekerjaan yang dilakukan, dialami, dan dirasakan oleh para karyawan sektor perbankan. Keseimbangan ini akan mencerminkan bagaimana para karyawan sektor perbankan selaku partisipan penelitian dalam bersikap dan berperilaku, serta dapat pula mengungkap hal-hal dan peristiwa apa saja yang pernah dialami oleh mereka. 


\section{Keseimbangan Kehidupan dan Pekerjaan dan Dimensi-Dimensinya}

Keseimbangan kehidupan dan pekerjaan atau dalam teori keilmuan sering disebut juga sebagai Work-Life Balance merupakan sebuah metafora. Dalam kamus bahasa, kata "keseimbangan" memiliki variasi makna yang kompleks. Keseimbangan berarti memiliki distribusi atau porsi yang sama. Selanjutnya, keseimbangan kehidupan dan pekerjaan disiratkan memiliki bobot yang sama. Keseimbangan kehidupan dan pekerjaan berkaitan dengan arti fisik dan psikologis sebagai stabilitas antara tubuh dan pikiran. Hal yang sama mengenai istilah keseimbangan kehidupan dan pekerjaan merujuk pada istilah untuk mengakomodasi kenyamanan dalam bekerja dan menghabiskan sisa hidup secara bahagia (Guest, 2002). Keseimbangan kehidupan dan pekerjaan adalah tentang mengelola dan mengatur tindakan secara efektif antara pekerjaan dan semua aktivitas penting lainnya di luar dari ranah pekerjaan sehingga bermanfaat bagi keluarga, masyarakat, lingkungan kerja sukarela, pengembangan diri, dan pemanfaatan waktu luang (Rahman, 2019). Secara historis, urusan pekerjaan dan kebutuhan diri dianggap sebagai domain terpisah, namun saat ini keterkaitan antara keduanya telah berevolusi. Adanya temuan bahwa cara seseorang dalam bekerja dapat mempengaruhi kehidupan berkeluarga, begitu pula sebaliknya, cara hidup yang berkembang di keluarga, termasuk pengambilan keputusan yang melibatkan keluarga akan mempengaruhi segala hal terkait pekerjaan. Efek positif dari hubungan keduanya akan kembali pada kesejahteraan diri seseorang (Burke, 2004).

Terdapat empat dimensi keseimbangan kehidupan dan pekerjaan atau work-life balance (WLB) oleh Fisher et al. (2009) yang digunakan pada penelitian ini, yaitu:

\section{Kehidupan Pribadi Mengganggu Pekerjaan}

Kehidupan Pribadi Mengganggu Pekerjaan atau Personal Life Interference with Work (PLIW) diartikan sebagai kehidupan sehari-hari yang dijalani oleh seseorang dan dapat mendatangkan kesenangan, namun justru menyebabkan kemunduran dari segi karir dan segala tata kelola aktivitas bekerja. Seseorang akan berusaha untuk mencapai sesuatu yang dicita-citakan di dalam kehidupannya, namun apabila ia terlalu fokus mengejarnya maka akan terjadi pengabaian terhadap tugas serta tanggung jawab pada pekerjaannya. Dalam konteks ini, aktivitas bekerja dan situasi pekerjaan tidak diuntungkan (Nyberg et al., 2018). Pada saat yang sama, berbagai aktivitas pribadi dan tuntutan kualitas hidup keluarga akan menghalangi tanggung jawab pekerjaan. Kemudian, adanya konflik pribadi juga akan mempengaruhi emosi seseorang sehingga memberikan berkontribusi negatif pada komitmen waktu kerja, keterlibatan kerja, kepuasan kerja, dan fleksibilitas kerjanya. Konflik pribadi biasanya muncul karena tuntutan peran dan kebutuhan hidup. Secara khusus, dimensi ini menempatkan kehidupan pribadi serta berkeluarga sebagai sebab dan segala hal terkait pekerjaan sebagai akibat (Judge et al., 2006).

\section{Pekerjaan Mengganggu Kehidupan Pribadi}

Pekerjaan Mengganggu Kehidupan Pribadi atau Work Interference with Personal Life (WIPL) diartikan sebagai aktivitas produktif yang mendatangkan keuntungan terutama dari segi finansial menjadi lebih diutamakan dan cenderung menyita banyak waktu pribadi. Peningkatan jam kerja dan beban kerja secara konsisten menghasilkan kehidupan pribadi yang negatif (Jacob et al., 2008). Pengaruh negatifnya tercermin pada sikap, perilaku, dan 


\section{Mochammad Eric Suryakencana Wibowo, Evanea S. Hartono}

hasil. Sebagai akibat dari jam kerja yang tidak fleksibel, keterlibatan pada pekerjaan secara berlebihan, dan stres kerja, maka dapat menghasilkan tekanan dalam hubungan keluarga, penarikan diri terhadap tanggung jawab keluarga, dan mempengaruhi kualitas hidup seseorang secara keseluruhan (Ahmad, 2008).

\section{Kehidupan Pribadi Meningkatkan Kualitas Pekerjaan}

Kehidupan Pribadi Meningkatkan Kualitas Pekerjaan atau Personal Life Enhancement of Work (PLEW) diartikan sebagai kehidupan sehari-hari yang dijalani oleh seseorang dimana di dalamnya terdapat berbagai kegiatan menyenangkan dan berkorelasi positif terhadap peningkatan kinerja seseorang, baik itu di tempat kerja maupun di dalam organisasi. Seseorang yang memiliki kesejahteraan subjektif tinggi pada kehidupannya akan memiliki kesehatan yang lebih baik, tingkat kehadiran penuh di tempat kerja, pengaturan diri yang baik, selalu termotivasi, mampu meningkatkan kreativitas, memiliki hubungan positif dengan rekan kerja, dan menghindari turnover di perusahaan (Tenney et al., 2016). Karyawan yang bahagia adalah karyawan yang produktif, demikian ungkapan umum guna mencerminkan bahwa kebahagiaan dan tingkat kesejahteraan yang lebih tinggi akan berdampak pada peningkatan kinerja dan pengaturan kerja (Patel \& Wolfe, 2019). Peningkatan taraf hidup berhubungan dengan kesejahteraan finansial. Mereka yang bekerja dan merasa tingkat kepuasaan hidupnya lebih tinggi menunjukkan bukti bahwa mereka memiliki tingkat stres pekerjaan yang lebih rendah (Hessels et al., 2017).

\section{Pekerjaan Meningkatkan Kualitas Kehidupan Pribadi}

Pekerjaan Meningkatkan Kualitas Kehidupan Pribadi atau Work Enhancement of Personal Life (WEPL) diartikan sebagai aktivitas produktif yang dilakukan oleh seseorang guna memenuhi kebutuhan hidup serta peningkatan kesejahteraan keluarga. Saat seseorang mampu menyelesaikan tugas dan tanggung jawab pekerjaannya secara baik, serta komunikasi dan koordinasi di tempat kerja terjalin secara harmonis, maka ia tidak akan mengalami stres di tempat kerja. Emosional diri akan bereaksi positif dan menunjukkan tingkat kemajuan. Pada saat yang sama, dampak pada kehidupan pribadi dan pemenuhan kebutuhan individu akan berjalan dengan mudah. Karyawan yang dibebaskan untuk melakukan apa pun dan kapan pun, selama pekerjaan selesai, hal ini yang justru akan membantu karyawan menjadi lebih fokus, produktif, dan efisien dalam bekerja sambil dapat memenuhi kebutuhan, tujuan, dan tanggung jawab pribadinya (Perlow \& Kelly, 2014). Kesuksesan kerja selalu diukur oleh hasil dan pencapaian. Hal yang dieksplorasi termasuk dampaknya terkait kesuksesan dalam kehidupan, persepsi emosional yang sehat dan pengelolaan konflik. Hasil dan pencapaian disertakan guna mempersepsikan keberhasilan dalam kehidupan pribadi. Hubungan keluarga yang terbentuk secara positif termasuk salah satu keberhasilan kehidupan pribadi (Jacob et al., 2008).

\section{Metode Penelitian}

Penelitian ini menggunakan metode kualitatif. Metode ini dipilih dan dirasa paling tepat karena peneliti ingin mengetahui secara langsung mengenai hal-hal dan peristiwa apa saja yang pernah dialami maupun dirasakan oleh partisipan penelitian. Metode kualitatif diyakini dapat mengungkap dan menjawab mengapa seseorang bersikap dan berperilaku dengan cara-cara tertentu terhadap permasalahan yang dihadapi (Oun \& Bach, 2014). Metode kualitatif paling tepat digunakan pada masalah dan fenomena yang masih menjadi misteri, 


\section{Mochammad Eric Suryakencana Wibowo, Evanea S. Hartono}

sehingga perlu diungkap secara langsung berdasarkan dari sudut pandang partisipan (Hilal et al., 2013). Penelitian kualitatif juga dianggap sebagai metode dalam pendekatan subjektif yang bertujuan menjelaskan serta menyoroti lika-liku pengalaman kehidupan seseorang (Khan, 2014).

Dalam penelitian kualitatif terdapat berbagai macam pendekatan yang dapat dipilih, seperti contohnya fenomenologi, grounded theory, studi kasus, historis dan etnography. Namun, peneliti lebih memilih untuk menggunakan pendekatan fenomenologi pada penelitian ini. Pendekatan fenomenologi merupakan pendekatan yang paling cocok digunakan dalam penelitian ini karena berdasarkan dari temuan fenomena-fenomena diawal, selanjutnya masih perlu dilanjutkan dengan pengambilan data primer. Selain itu, peneliti ingin mengidentifikasi serta menganalisis tentang keseimbangan kehidupan dan pekerjaan yang dilakukan, dialami, dan dirasakan oleh para karyawan sektor perbankan. Keseimbangan ini akan mencerminkan bagaimana para karyawan sektor perbankan dalam bersikap dan berperilaku. Pendekatan fenomenologi merupakan pendekatan untuk mempelajari maupun memahami sebuah pengalaman hidup seseorang (Tuffour, 2017).

Adapun teknik yang digunakan untuk pengambilan data menggunakan kegiatan observasi obyek penelitian dan dilanjutkan dengan melakukan in-depth interview. In-depth interview atau wawancara mendalam bertujuan memperoleh hal-hal secara mendetail mengenai fenomena atau masalah yang sedang diteliti. Selanjutnya, perolehan data in-depth interview ini dapat dianalisis dengan menggunakan Interpretative Phenomenological Analysis (IPA). Pengambilan data penelitian dilakukan selama kurang lebih 2 minggu atau dimulai sejak bulan Januari 2020. Proses pengambilan data dengan kegiatan wawancara ini didokumentasikan ke dalam bentuk audio dan visual.

\section{Sampel dan Populasi}

Sampel dan populasi pada penelitian ini menyasar pada karyawan yang bekerja di salah satu bank swasta di Kota Semarang. Dalam sebuah penelitian kualitatif, prinsip pseudonyms menjadi salah satu atribut penelitian. Adanya etika untuk mengaburkan informasi pribadi, nama, pekerjaan, hingga jenis kelamin menjadi karakteristik penyamaran. Aturan dan kebiasaan seputar anonimitas lebih menegaskan bahwa pentingnya melindungi kerahasiaan, independensi, dan sosiokultural mereka (Allen \& Wiles, 2016). Tanggung jawab atas anonimitas partisipan berada di tangan peneliti dan partisipan membutuhkan perlindungan di setiap tahap penelitian (Creswell, 2013). Oleh karenanya, nama bank yang dijadikan sebagai obyek penelitian beserta nama-nama partisipan yang terlibat di dalam penelitian ini telah peneliti samarkan. Nama bank swasta tersebut peneliti tuliskan sebagai Bank Gunungan. Bank Gunungan merupakan salah satu bank swasta nasional terbesar di Indonesia. Bank ini berada di tengah-tengah pusat Kota Semarang. Bank Gunungan memiliki jam bekerja mulai pukul 08.00 WIB sampai dengan 17.00 WIB. Adapun partisipan yang bersedia terlibat di dalam penelitian ini berjumlah 7 orang.

Mereka bekerja sebagai karyawan bank dengan berbagai macam posisi dan jabatan. Masing-masing dari para karyawan tentunya memiliki tugas, tanggung jawab dan pemanfaatan waktu yang berbeda-beda. Hal-hal inilah yang dirasa tepat untuk mengetahui struktur keseimbangan dalam kehidupan dan pekerjaan mereka. Penentuan partisipan tidak terbatas oleh kategori usia, jenis kelamin, maupun posisi dan jabatan. Hanya saja, syarat utama yang menjadi acuan peneliti dalam mencari partisipan yang tepat adalah partisipan 


\section{Mochammad Eric Suryakencana Wibowo, Evanea S. Hartono}

harus bekerja di sektor perbankan dan peneliti harus mendapatkan partisipan-partisipan yang telah menikah dan berkeluarga. Bobot aktivitas para partisipan yang telah menikah dan berkeluarga tentunya berbeda dan dirasa lebih berat ketimbang dengan mereka-mereka yang belum menikah.

Berikut ini adalah profil partisipan yang bersedia terlibat dalam penelitian dan telah diwawancarai:

1. Ibu Ceremai selaku partisipan ke-1.

Adalah seorang wanita berusia 40 tahun, telah menikah dan dikaruniai 2 orang anak, telah bekerja selama 20 tahun, dengan jabatan saat ini sebagai Manajer Kredit Administrasi dan memiliki gaji sekitar Rp. 14.000.000,- per bulannya.

2. Ibu Kerinci selaku partisipan ke-2.

Adalah seorang wanita berusia 44 tahun, telah menikah dan tidak memiliki anak, telah bekerja selama 20 tahun, dengan jabatan saat ini sebagai Manager Secure Credit dan memiliki gaji sekitar Rp. 13.000.000,- per bulannya.

3. Bapak Bromo selaku partisipan ke-3.

Adalah seorang Pria berusia 43 tahun, telah menikah dan dikaruniai 2 orang anak, telah bekerja selama 10 tahun, dengan jabatan saat ini sebagai Loan Document Safe Keeping Staff dan tidak bersedia menyebutkan nominal pendapatannya.

4. Bapak Galunggung selaku partisipan ke-4.

Adalah seorang Pria berusia 43 tahun, telah menikah dan dikaruniai 2 orang anak, telah bekerja selama 13 tahun, dengan jabatan saat ini sebagai Asisten Manajer dan tidak bersedia menyebutkan nominal pendapatannya.

5. Ibu Tampomas selaku partisipan ke-5.

Adalah seorang wanita berusia 35 tahun, telah menikah dan dikaruniai 1 orang anak, telah bekerja selama 7 tahun, dengan jabatan saat ini sebagai Loan Document Safe Keeping Staff dan memiliki gaji sekitar Rp. 7.500.000,- per bulannya.

6. Bapak Tidar selaku partisipan ke-6.

Adalah seorang Pria berusia 38 tahun, telah menikah dan dikaruniai 3 orang anak, telah bekerja selama 9 tahun, dengan jabatan saat ini sebagai Loan Document Safe Keeping Staff dan memiliki gaji sekitar Rp. 7.500.000,- per bulannya.

7. Ibu Serayu selaku partisipan ke-7.

Adalah seorang wanita berusia 52 tahun, telah menikah dan dikaruniai 1 orang anak, telah bekerja selama 22 tahun, dengan jabatan saat ini sebagai Section Head dan memiliki gaji sekitar Rp. 12.000.000,- per bulannya.

\section{Data Deskriptif}

Peneliti telah berhasil melakukan kegiatan wawancara kepada 7 orang pegawai bank selaku partisipan penelitian. Dalam dunia perbankan terdapat berbagai tingkat jabatan dan golongan. Sementara itu, seluruh pegawai bank yang bersedia terlibat menjadi partisipan dalam penelitian ini memiliki uraian jabatan dan peran yang berbeda-beda. Perbedaan tingkat jabatan dan golongan inilah yang dapat menunjukkan seberapa padatnya tingkat kesibukan mereka sehingga nantinya akan diketahui bagaimana keseimbangan kehidupan dan pekerjaan 


\section{Mochammad Eric Suryakencana Wibowo, Evanea S. Hartono}

atau work-life balance yang mereka alami dan rasakan. Kegiatan pengambilan data dimulai dengan proses kegiatan wawancara yang kemudian didokumentasikan ke dalam bentuk rekaman suara dan rekaman video. Hal ini dilakukan guna mempermudah peneliti ketika akan mengubah konten dari hasil rekaman tersebut menjadi bentuk transkrip wawancara. Nantinya bentuk transkrip wawancara tersebut akan siap untuk diolah lebih lanjut.

Peneliti pertama kali bertemu dengan Ibu Ceremai selaku Manajer Kredit Administrasi di bank tersebut. Kedatangan peneliti disambut baik oleh yang bersangkutan. Setelah menyampaikan maksud kedatangan peneliti, beliau kemudian bersedia menjadi partisipan pertama yang peneliti wawancarai. Proses pengambilan data berupa kegiatan wawancara yang berjalan lancar selama kurang lebih 25 menit. Seusai melakukan kegiatan wawancara dengan beliau, peneliti mulai dipertemukan dengan Ibu Kerinci selaku partisipan ke-2, Bapak Galunggung selaku partisipan ke-4, dan keduanya bersedia untuk diwawancarai saat itu juga. Tiga hasil wawancara telah peneliti kantongi, selang beberapa hari berikutnya, peneliti diizinkan untuk melakukan kegiatan wawancara lanjutan dan mulai dipertemukan dengan Bapak Bromo selaku partisipan ke-3, Ibu Tampomas selaku partisipan ke-5, dan Bapak Tidar selaku partisipan ke-6. Ketiganya merupakan karyawan bank yang bekerja dalam satu divisi. Pengambilan data berupa kegiatan wawancara kemudian diakhiri dengan diwawancarainya Ibu Serayu selaku partisipan ke-7.

Berbekal data primer dari hasil wawancara yang telah peneliti miliki, peneliti meyakini bahwa apa yang dituturkan oleh seluruh partisipan terkait keseimbangan kehidupan dan pekerjaan yang selama ini mereka alami, rasakan, dan lakukan adalah benar adanya. Keyakinan ini bertujuan membangun sebuah kredibilitas, baik pada data yang disajikan maupun hasil pembahasannya. Peneliti mendapati bahwa faktor pendapatan, problematika eksternal, dan lingkungan juga sangat berpengaruh dalam mencerminkan serta menggarisbawahi lika-liku perjalanan kehidupan dari masing-masing partisipan.

Selanjutnya, dari hasil rekaman suara dan rekaman video yang telah peneliti dapatkan, hasil tersebut kemudian diolah menjadi bentuk transkrip wawancara berupa kata-kata. Dari bentuk transkrip wawancara tersebut, peneliti memindahkannya ke dalam bentuk matriks hasil wawancara. Pada matriks hasil wawancara, peneliti mulai melakukan identifikasi dan pengelompokkan sesuai dengan codes yang muncul. Codes dipilih berdasarkan dari kata-kata yang memiliki kesamaan makna sehingga mulai mengerucut menjadi kelompok kata bermakna umum, dan ini biasa disebut sebagai sub categories. Temuan kelompok bermakna umum yang disebut sub categories tadi kemudian dikelompokkan kembali menjadi kesatuan kata bermakna luas dan ini biasa disebut sebagai categories. Karena pada teori awal peneliti telah menggunakan empat dimensi keseimbangan kehidupan dan pekerjaan yang dicetuskan oleh Fisher et al. (2009), maka peneliti tidak perlu mencari lagi kesatuan kelompok kata dari categories yang telah ditemukan.

\section{Pembahasan}

Keseimbangan kehidupan dan pekerjaan menjadi penentu apakah seseorang mampu menyeimbangkan antara kehidupan pribadinya dengan urusan pekerjaannya. Keseimbangan kehidupan dan pekerjaan memiliki empat dimensi utama yang dapat digunakan sebagai pedoman penelitian. Masing-masing dimensi telah peneliti dalami berdasarkan dari pertanyaan yang telah diajukan dan dijawab oleh para partisipan, sehingga peneliti mampu melihat berbagai temuan fakta yang muncul di dalam penelitian ini. Maka, berdasarkan hasil olah data dan temuan akhir dari penelitian ini, peneliti menguraikan sebagai berikut: 
1. Kehidupan Pribadi Mengganggu Pekerjaan atau Personal Life Interference with Work (PLIW)

Dari hasil wawancara, Karyawan Bank Gunungan diidentifikasi memiliki permasalahan dalam kehidupan pribadinya. Permasalahan yang paling dominan muncul adalah ketika kebutuhan pribadi tidak terpenuhi, selalu memikirkan urusan pekerjaan yang tidak kunjung selesai, kesadaran bahwa antara kehidupan pribadi dan urusan pekerjaan adalah dua hal yang tidak bisa dicampuradukkan, kurangnya pengendalian terhadap masalah pribadi, banyak kekhawatiran akan pemenuhan kebutuhan pribadi dan keluarga, tidak dapat mengontrol diri dan pikiran sehingga beban pekerjaan selalu membayangi, kurang berpengalaman dalam menyelesaikan permasalahan rumah tangga, dan berprinsip pada kehidupan sederhana adalah kuncinya, namun mereka tidak siap akan hal tersebut. Meski kehidupan pribadinya dinyatakan sebagai kehidupan harmonis dan merasa telah dijalankan secara sederhana, namun pada kenyataannya temuan paling dominan justru mengacu pada faktor-faktor kehidupan pribadi yang bersifat negatif (seperti diatas tadi) yang dapat menganggu segala urusan pekerjaan mereka. Maka dengan ini, kehidupan pribadi terbukti mengganggu pekerjaan.

\section{Pekerjaan Mengganggu Kehidupan Pribadi atau Work Interference with Personal Life} (WIPL)

Dari hasil wawancara, Karyawan Bank Gunungan diidentifikasi memiliki permasalahan dalam urusan pekerjaannya. Permasalahan yang paling sering muncul adalah durasi waktu bekerja yang berlebih, emosi dan tenaga yang terkuras habis, kelelahan sehingga tidak sempat mengurus rumah dan melayani keluarga, mayoritas partisipan sering membawa urusan pekerjaan sampai pulang ke rumah, tuntutan dan tekanan kerja berlebih, memiliki keterbatasan waktu untuk bersenang-senang karena harus mengabdikan diri pada pekerjaan, tugas dari atasan dirasa tidak ada habisnya, partisipan membutuhkan motivator dan penyemangat, tingkat kesulitan penyelesaian pekerjaan yang dirasa bertingkat dan kompleks, serta merasakan gangguan mental seperti stres, depresi, kelalahan akut, dan ketakutan. Meski berstatus sebagai karyawan bank mampu mendorong aktualisasi diri dan tingkat kepercayaan diri mereka, namun pada kenyataannya mereka paling sering merasakan dampak negatif dari urusan pekerjaannya. Maka dengan ini, pekerjaan terbukti mengganggu kehidupan pribadi.

\section{Kehidupan Pribadi Meningkatkan Kualitas Pekerjaan atau Personal Life Enhancement of} Work (PLEW)

Dari hasil wawancara, Karyawan Bank Gunungan diidentifikasi juga memiliki berbagai lika-liku problematika di dalam kehidupan pribadinya. Faktor-faktor positif dalam kehidupan pribadi para partisipan, seperti adanya dukungan (support) dan motivasi ekstrinsik kepada diri mereka justru secara berimbang berhadapan langsung dengan faktor-faktor yang tidak meningkatkan kualitas pekerjaan mereka. Contohnya seperti ketidakstabilan emosi dan kelelahan kerja, merupakan faktor dominan yang menurunkan kualitas kehidupan mereka. Jadi dengan kata lain, para partisipan secara dilematis harus merasakan bahwa adanya hal-hal postif dalam kehidupan pribadinya, akan tetapi ini tidak juga meningkatkan kualitas pekerjaan mereka karena perasaan yang paling sering mereka rasakan adalah bahwa urusan 


\section{Mochammad Eric Suryakencana Wibowo, Evanea S. Hartono}

pekerjaan dan kehidupan pribadi tidak dapat dicampuradukkan. Maka dengan ini, kehidupan pribadi tidak sepenuhnya terbukti dapat meningkatkan kualitas pekerjaan.

\section{Pekerjaan Meningkatkan Kualitas Kehidupan Pribadi atau Work Enhancement of Personal Life (WEPL)}

Dari hasil wawancara, Karyawan Bank Gunungan diidentifikasi sering merasakan bahwa pekerjaan dapat meningkatkan kualitas kehidupan pribadi, namun dapat pula menurunkan kualitas kehidupan pribadi. Para partisipan diketahui sangat mengutamakan urusan pekerjaannya. Mereka bekerja untuk mendapatkan gaji. Dalam konteks pemenuhan kebutuhan dan perolehan gaji, pekerjaan terlihat mampu meningkatkan kualitas kehidupan pribadi serta taraf hidup mereka. Namun, apabila dilihat dari konteks psikologis dan sisi pengaturan diri, faktor stres, kelelahan, dan ketidakmampuan untuk mengatur berbagai macam hal, justru menjadi pendorong penurunan kualitas kehidupan pribadi mereka. Secara berimbang, antara kehidupan pekerjaan dan kehidupan pribadi sama-sama berada pada posisi yang sama dan harus diutamakan. Keduanya tidak dapat ada yang dapat dinomorduakan atau dikesampingkan. Hubungan diantara kedua hal tersebut dapat dikatakan menguntungkan (meningkat), namun juga dapat merugikan (menurunkan). Maka dengan ini, dimensi pekerjaan tidak sepenuhnya terbukti dapat meningkatkan kualitas kehidupan pribadi.

\section{Kesimpulan}

Dari hasil pembahasan mengenai keseimbangan kehidupan dan pekerjaan yang telah dianalisis dari para karyawan Bank Gunungan, maka dapat diketahui bahwa antara kehidupan pribadi dan urusan pekerjaan adalah dua hal yang berbeda. Keduanya tidak dapat dicampuradukkan, namun keduanya berada pada skala prioritas utama yang harus dilakukan. Para karyawan Bank Gunungan sebagai partisipan sangat menyadari secara penuh akan hal tersebut. Mereka mengisyaratkan seperti memiliki dua dunia yang berbeda ketika harus berhadapan dengan dua kehidupan tersebut.

Ketika sedang larut dalam aktivitas bekerja, mereka seringkali teringat tentang bagaimana kegiatan pribadi begitu menyenangkan untuk dilakukan dan terbesit kondisi keluarga di rumah. Begitu pula sebaliknya, ketika mereka tengah menikmati waktu bersantai dan melakukan kegiatan yang mereka senangi (berolahraga, menonton televisi, berkumpul dengan teman dan keluarga), seketika itu juga mereka harus menghentikan kegiatan tersebut karena teringat dengan tugas pekerjaan yang tak kunjung selesai. Jadi, dua domain kehidupan tersebut tidak serta merta dapat mengisi kekurangan satu sama lain, karena keduanya telah memiliki porsi yang sama dan menempati skala prioritas utama untuk dilakukan.

Penelitian ini memberikan kontribusi keilmuan pada bidang manajemen sumber daya manusia dengan menunjukkan bahwa keseimbangan tidak selalu harus mengintergrasikan dua domain berbeda, tetapi juga dapat memisahkannya. Sepertinya yang telah terungkap dari penelitian ini bahwa kehidupan pribadi dan urusan pekerjaan adalah dua hal yang berbeda. Para partisipan memperlakukan pekerjaan seolah-olah itu bukan bagian dari hidup. Tidak semua orang ingin memberikan bobot yang sama ketika sedang bekerja dan melakukan kegiatan pribadi yang menyenangkan. Mereka harus memilih salah satu diantara keduanya, namun tidak berarti harus mengorbankan yang lainnya. Dan demikianlah, keseimbangan yang selama ini dilakukan oleh seluruh partisipan selama berprofesi sebagai karyawan Bank Gunungan. 


\section{Implikasi dan Agenda Penelitian}

Keseimbangan kehidupan dan pekerjaan hingga saat ini masih diteliti sebagai sesuatu yang menyatakan takaran atau tolak ukur dalam menentukan apakah seseorang telah dapat seimbang atau belum dalam menjalankan kehidupan pribadi dan pekerjaannya. Padahal kenyataannya, masih terdapat fakta-fakta terbaru yang mungkin saja muncul ketika dilakukan penggalian informasi secara lebih mendalam. Dari hasil penelitian sendiri diketahui bahwa antara kehidupan pribadi dan pekerjaan tidak dapat dicampuradukkan, ini membuka tabir bahwa para partisipan yang berprofesi seorang karyawan bank, terlihat tidak mampu dalam membagi waktu dan melakukan pengaturan diri. Berpijak pada hal ini, diharapkan agar mereka dapat memperbaiki tata kelola waktu (time management) serta dapat menyusun agenda-agenda aktivitas secara lebih terstruktur agar segala aktivitas pada dua kehidupan tersebut tidak saling berbenturan dan dapat dilakukan secara bergantian. Jika ini dilakukan, pasti akan terasa dampak positifnya pada diri seluruh partisipan.

Agenda untuk penelitian mendatang diharapkan agar peneliti selanjutnya dapat melakukan penelitian lebih lanjut tentang keseimbangan kehidupan dan pekerjaan, tidak hanya dari sektor perbankan saja, akan tetapi dapat merambah pada berbagai kalangan profesi dari segala sektor. Masih banyak kalangan profesi dengan tingkat kesibukan dan kepadatan aktivitas yang tinggi, sehingga hal ini dianggap cocok dan sangat berpeluang untuk diteliti. Selain itu, penelitian mendatang dapat menambah khasanah keilmuan pada bidang manajemen serta dapat mengungkap deretan fakta-fakta terbaru terkait keseimbangan kehidupan dan pekerjaan. Metode penelitian selanjutnya dapat pula menerapkan metode penelitian lainnya, sehingga tidak harus sama dengan apa yang peneliti gunakan dalam penelitian ini.

\section{Daftar Pustaka}

Ahmad, A. (2008) "Job, Family and Individual Factors as Predictors of Work-Family Conflict". The Journal of Human Resource and Adult Learning, 4(1), 57-65.

Allen, R. E. S., \& Wiles, J. L. (2016) "A rose by any other name: participants choosing research pseudonyms". Qualitative Research in Psychology, 13(2), 149-165.

Burke, R. J. (2004) "Work and personal life integration". International Journal of Stress Management, 11(4), 299-304.

Creswell, J. (2013) "Qualitative Inquiry \& Research Design: Choosing Among Five Approaches". In SAGE Publications (Vol. 11).

Fisher, G. G., Bulger, C. A., \& Smith, C. S. (2009) "Beyond Work and Family: A Measure of Work/Nonwork Interference and Enhancement". Journal of Occupational Health Psychology, 14(4), 441-456.

Franche, R. L., Williams, A., Ibrahim, S., Grace, S. L., Mustard, C., Minore, B., \& Stewart, D. E. (2006) "Path analysis of work conditions and work-family spillover as modifiable workplace factors associated with depressive symptomatology". Stress and Health, 22(2), 91-103.

Guest, D. E. (2002) "Perspectives on the study of work-life balance". Social Science Information, 41(2), 255-279. 
Hessels, J., Rietveld, C. A., \& van der Zwan, P. (2017) "Self-employment and work-related stress: The mediating role of job control and job demand". Journal of Business Venturing, 32(2), 178-196.

Hilal AlYahmady, H., \& Said Al Abri, S. (2013) "Using Nvivo for Data Analysis in Qualitative Research". In International Interdisciplinary Journal of Education (Vol. 2).

Hossain, M. I., Limon, N., Amin, M. T., \& Asheq, A. S. (2018) "Work Life Balance Trends: A Study on Malaysian GenerationY Bankers". IOSR Journal of Business and Management, 20(9), 1-9.

Jacob, J. I., Allen, S., Hill, E. J., Mead, N. L., \& Ferris, M. (2008) "Work interference with dinnertime as a mediator and moderator between work hours and work and family outcomes". Family and Consumer Sciences Research Journal, 36(4), 310-327.

Judge, T. A., Ilies, R., \& Scott, B. A. (2006) "Work-family conflict and emotions: Effects at work and at home". Personnel Psychology, 59(4), 779-814.

Khan, S. N. (2014) "Qualitative research method - Phenomenology". Asian Social Science, 10(21), 298-310.

Lockwood, N. R. (2003) "Work/Life Balance: Challenges and Solutions for Human Resource Management". SHRM Research, (Research Quarterly), 1-10.

Nyberg, A., Peristera, P., Bernhard-Oettel, C., \& Leineweber, C. (2018) "Does work-personal life interference predict turnover among male and female managers, and do depressive symptoms mediate the association? A longitudinal study based on a Swedish cohort". BMC Public Health, 18(1), 1-12.

Oun, M. A., \& Bach, C. (2014) "Qualitative Research Method Summary". Journal of Multidisciplinary Engineering Science and Technology (JMEST), 1(5), 3159-3199.

Patel, P. C., \& Wolfe, M. T. (2019) "Money might not make you happy, but can happiness make you money? The value of leveraging subjective well-being to enhance financial well-being in self-employment". Journal of Business Venturing Insights, 12(June).

Perlow, L. A., \& Kelly, E. L. (2014) "Toward a Model of Work Redesign for Better Work and Better Life". Work and Occupations, 41(1), 111-134.

Rahman, M. F. (2019) "Work- Life Balance as an Indicator of Job Satisfaction Among the Female Bankers in Bangladesh". European Journal of Business and Management, 11(6).

Rajendran, R., \& Geetha, S. (2017) "Comparative Study of Work Life Balance Among Private and Public Sector Banking Employees in Perambalur District". IJRDOJournal of Applied Management Science, 3(11), 1-7.

Tenney, E. R., Poole, J. M., \& Diener, E. (2016) "Does positivity enhance work performance?: Why, when, and what we don't know". Research in Organizational Behavior, 36, 27-46.

Tuffour, I. (2017) "A Critical Overview of Interpretative Phenomenological Analysis: A Contemporary Qualitative Research Approach". Journal of Healthcare Communications, 02(04), 1-5. 